\title{
Ethnoconstructivism analysis: Study of pedagogic mathematics competence of primary school teachers
}

\author{
Syahrial, Asrial, Maison, Amirul Mukminin, Dwi Agus Kurniawan \\ Faculty of Teaching and Education, Universitas Jambi, Indonesia
}

\begin{tabular}{l} 
Article Info \\
\hline Article history: \\
Received Aug 23, 2019 \\
Revised Mar 10, 2020 \\
Accepted Jul 22, 2020 \\
\hline Keywords: \\
Elementary teacher \\
Ethnoconstructivism \\
Mathematics learning \\
Teacher
\end{tabular}

Corresponding Author:

Syahrial,

Faculty of Teaching and Education,

Universitas Jambi,

Jln. Jambi - Muara, Bulian, KM.15, Jambi, 36361 Indonesia.

Email: syahrial.karea@gmail.com

\begin{abstract}
The teacher has an important role in realizing quality learning. Qualified teachers are shown with good competence. Teacher competency can be improved through teacher understanding of non-constructivism knowledge in mathematics learning. Teachers can integrate cultural values and local wisdom into mathematical concepts to shape student knowledge. Integrating cultural values and local wisdom into mathematics learning makes students learn through their cultural background experiences. This research was a descriptive research employed 691 respondents. The instruments in this study were questionnaires, tests and interviews to reinforce quantitative results. The purpose of this study was to determine the level of teacher pedagogical knowledge, teacher ethnoconstructivism knowledge, the influence and impact of ethnoconstivism knowledge in mathematics learning. The results of this study indicate the competence of elementary school teachers in Batanghari, Muaro Jambi, and Jambi City tends to be generally not good, and teachers have applied ethno-constructivism in mathematics learning through the use of media, models, and learning strategy. Teachers still encounter many obstacles in the implementation process. And the age range of the teacher has an impact on the level of ethnoconstructivism knowledge in mathematics learning.
\end{abstract}

This is an open access article under the CC BY-SA license.

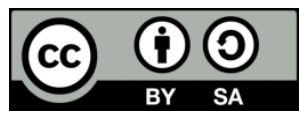

\section{INTRODUCTION}

The teacher is an important instrument in realizing good learning. Good learning can be supported by a good teacher competency. Competencies as the ability to perform tasks in a specific situation, for instance a classroom situation, in a flexible and adaptive fashion [1]. Teacher competencies that must be mastered are pedagogical, professional, personality and social competence. According Law No. 14 of 2005 article 10 "teacher competencies that are mandatory for teachers include pedagogic competence, personality competence, social competence and professional competencies obtained through professional education". Teachers who have good competence will produce students who are successful in learning. Pedagogical competence can be described as a teacher's ability and will to regularly apply the attitude, knowledge and skills that promote student learning [2-4].

Pedagogic competence is one of the most important competencies. It was described as an integration of teachers' pedagogical knowledge and content knowledge into a 'special form of professional understanding' [5-7]. From his point of view, the teacher should not only reflect in general, but also must use 
certain concepts and ideas to be reflected, such as teaching methods, teaching materials, communication with students, cooperation with coworkers [8]. Pedagogic competencies include things that are a very principle in learning such as teaching skills, evaluation, and assessment. Pedagogical Knowledge (PK): PK relates to teaching methodologies and approaches, including knowledge in teaching and classroom management, assessment, evaluation, development of lesson plans (RPP), and student learning [9]. According to Act No. 16 of 2007 point 1 Pedagogical Competence of teachers must understand the characteristics of students from physical, moral, social, cultural, emotional and intellectual aspects [10]. Teachers Professional Identity: 1) is (re) structured during the continuous and uninterrupted process of interpretation, and self-reflection on teachers' experiences, 2) is the interaction between individual characteristics and the social context, and consequently there is no single and unique Professional Identity, 3) consists of individual Sub-Identities, some of which are in harmony with each other, while others in conflict. This shows that in carrying out learning, the teacher must integrate the cultural values and social-cultural background of the students. Shulman suggests that these sources of understanding make possible the process of pedagogical reasoning and action [11]. The model describes how a teacher's understanding of subject matter is transformed to make it 'teaching'. This process of transformation taps the different sources of knowledge, the most important being pedagogical content knowledge [11].

Basically, students have the initial knowledge that comes from the environment and experience. According to Bransford [12], Transfer can be improved by helping students become more aware of themselves as learners who actively monitor their learning strategies and resources for particular tests and performances. The teacher has the task and role in bridging the knowledge that students have with new knowledge to be learned. Considering the knowledge and conception of students is part of constructivism. The prior student considering the knowledge and conceptions is the most remarkable features of the view of learning [13]. The teacher must also guide and facilitate students in constructing their knowledge. Constructing students' knowledge can be done using the cultural values of students.

The field of mathematics education currently lacks models for the design and implementation of content courses aimed at developing pre-service teacher mathematics knowledge for teaching. Therefore, the researcher carries the learning of mathematics based on ethnoconstructivism. Ball and colleagues [14] identified several sub-components for teachers' disciplinary knowledge of mathematics, distinguishing between, for example, "specialized content knowledge" and "pedagogical content knowledge." We use the term specialized mathematics to encompass all components of disciplinary knowledge pertaining to teaching, acknowledging that much of the subtlety of their distinctions is omitted here [15]. One of the cultural values that contain a lot of learning value is on the mathematical aspects. Teaching skilled mathematics requires more than learning how to apply certain pedagogical tasks [16]. Therefore, learning is needed that is related to local culture. Ethno-constructivism values in the field of mathematics is an educational value that integrates between cultures viewed from a mathematical point of view. Mathematics is the science of thinking and it is important for improving the thinking potential in the learning process and understanding the causes and effects [17]. Ethnomathematics refers to forms of mathematics whose purpose is other than doing mathematics [18]. So ethnomathematics refers to mathematical values practiced in a cultural group. According to Cimen [19], ethnomathematics is the mathematics which is practiced among identifiable cultural groups such as national-tribe societies, labor groups, children of certain age brackets and professional classes. According to Arisetyawan in 2014 states that: Ethnomathematics, broadly defined that ethnomathematics study is not limited to small-scale groups, but the prefix "ethno" can refer to any group such as nation, labor unions, religious traditions, and so on [20]. It includes the use of mathematical symbols, spatial design, methods of calculation, measurement in space and time, specific ways of reasoning, and other human activities that can be translated into a formal mathematical representation and also in this field of study.

Learning objectives that integrate cultural values and local wisdom around students are to ensure students know the cultural values and local wisdom that are around them and students can maintain and preserve those values from the onslaught of cultures from other countries. Students can have a love for their culture and not lose their identity as a nation. Noble values, customs, and culture can encourage students to have a sense of pride and become the foundation for students to act in their daily lives. These very diverse values must be utilized by the teacher as a learning resource. According to Fouze, ethnomathematics is right to choose their own. In other words, mathematics can assist in promoting tolerance in an era of abundance that lacks it [21]. The goal of learning must be the discovery of new facts about the self, society, and culture of the learner, who must be able to make decisions and reconstruct the link between mathematical principles, concrete situations, and personal experience. All of these are essential to the balanced development of every country or society [21]. Therefore, teachers are expected to be able to carry out learning by integrating cultural values and local wisdom. Teachers are expected to develop lessons that can utilize local learning resources [22]. This study is intended to determine the ethnoconstivism in the field of mathematics to have

Ethnoconstructivism analysis: Study of pedagogic mathematics competence of primary school ... (Syahrial) 
an impact, implementation, constraints, and influence on pedagogical competence of elementary school teachers in Jambi Province, Indonesia.

\section{RESEARCH METHOD}

This study employed descriptive research methods. Descriptive approach is done because in this study will see the extent of knowledge of the elementary school ethnoconstivism teachers. Then to find out the pedagogical competence of elementary school teachers and see the effect of knowing ethnoconstructivism in the field of mathematics on teacher pedagogical competencies. The population in this study included elementary school teachers in Jambi Province. The research samples used were elementary school teachers in Batanghari Regency, Muaro Jambi Regency, and Jambi City, Indonesia as many as 691 teachers. The sampling technique used is the Cluster Sampling technique. In cluster sampling two or more elements or two units or more are included in the sample at each sample location [23]. The inclusion of two or more units/elements in each sample location intensified sampling efforts at each sample location. Cluster sampling was chosen because it made it easier for researchers to collect data from extensive research areas. Why Divided 3, based on the criteria applied by the researchers, the teachers who were sampled came from the City of Jambi, Batanghari, and Muaro Jambi. Teachers in the city are drawn because they are urban, and Batanghari and Muaro Jambi are two urban buffer districts because they are rural, detailing the number in each region is 301 for Jambi City, 205 for Batanghari and 185 for Muaro Jambi. Data collection in this study uses questionnaire instruments, multiple choice questions, interviews. The questionnaire is a technique of collecting data where participants or respondents fill in a question or statement later, after being filled in with a complete return to the researcher [24]. The purpose of the questionnaire is to look at the level of ethnoconstructivism knowledge of elementary school teachers. Table 1 shows categorization of value ranges for questionnaires; there are four categories, namely very good, good, not good, and very not good.

Data obtained from the questionnaire results will be analyzed using SPSS software and then processed into descriptive statistics. Descriptive data are in the form of mean, median, mode, and frequency. Then the researcher gave multiple choice questions to elementary school teachers with four choices of answer options. Multiple choice questions aim to look at the level of pedagogical competence of elementary school class teachers. Table 2 shows categorization of ranges of values for multiple choice tests; there are four categories, namely very good, good, not good and very not good.

Table 1. Categorization of the questionnaire value ranges

\begin{tabular}{cc}
\hline Category & Value Ranges \\
\hline Very Good & $47-57$ \\
Good & $36-46$ \\
Not Good & $25-35$ \\
Very Not Good & $14-24$ \\
\hline
\end{tabular}

Table 2. Categorization of the range of MCQs

\begin{tabular}{cc}
\hline Category & Value Ranges \\
\hline Very Good & $76-100$ \\
Good & $51-75$ \\
Not Good & $26-50$ \\
Very Not Good & $0-25$ \\
\hline
\end{tabular}

Data from multiple choice test questions were analyzed to be used as descriptive statistics. Multiple choice test questionnaire It has 6 indicators, namely being able to understand the learners, mastering learning theory and principles of learning that are educated, being able to make learning designs, being able to carry out that learning is educational and Dialogic, being able to evaluate learning outcomes and being able to develop students to actualize their various competencies. Then the researcher continued collecting data using structured interview instruments. Interviews were conducted for lower grade teachers, namely teachers in grades 1, 2, and 3 as well as high-class teachers, namely teachers in grades 4, 5, and 6. The purpose of the interview activities was to strengthen the questionnaire results and multiple choice questions. Interview data analyzed using Miles and Huberman with its stages, reducing, displaying, and then concluding [24].

\section{RESULTS AND DISCUSSION}

\subsection{Results}

Pedagogic competence is a competency that refers to the ability of a teacher to carry out learning including. Good mastery of pedagogical competencies shows the teacher has a professional attitude. According to Koutouzis \& Spiriadou in 2017 state that Teachers Professional Identity: 1) is (re) structured during continuous and uninterrupted process of interpretation, and self-reflection on teachers' experiences, 2 ) is the interaction between individual characteristics and the social context, and consequently there is no single and unique Professional Identity, 3) consists of individual Sub-Identities, some of which are in harmony with each other, while others in conflict [11]. Moreover, professional development is a key 
component, as teachers are in a constant process of development. The following are the results of the pedagogical competencies of elementary school teachers in Jambi City, Muaro Jambi District, and Batanghari District. This result was obtained through the activity of filling in multiple choice test questions as presented in Table 3 .

Table 3. Multiple choice test results pedagogic competence by gender

\begin{tabular}{|c|c|c|c|c|c|c|c|}
\hline & \multicolumn{3}{|c|}{ Male } & & \multicolumn{3}{|c|}{ Female } \\
\hline & Category & Frequency & $\%$ & & Category & Frequency & $\%$ \\
\hline & Very Good & 5 & 3.2 & & Very Good & 10 & 4.6 \\
\hline Low Class & Good & 16 & 10.5 & Low Class & Good & 29 & 13.2 \\
\hline \multirow[t]{2}{*}{ Teacher } & Not Good & 102 & 67.1 & Teacher & Not Good & 127 & 58 \\
\hline & Very Not Good & 29 & 19 & & Very Not Good & 53 & 24.2 \\
\hline \multirow[b]{3}{*}{$\mathrm{Hig}$} & & 152 & 100 & & Total & 219 & 100 \\
\hline & Very Good & 0 & 0 & & Very Good & 7 & 3.7 \\
\hline & Good & 23 & 17.7 & High Class & Good & 20 & 10.5 \\
\hline \multirow[t]{3}{*}{ Teacher } & Not Good & 70 & 53.8 & Teacher & Not Good & 134 & 70.5 \\
\hline & Very Not Good & 37 & 28.5 & & Very Not Good & 29 & 15.3 \\
\hline & & 130 & 100 & & Total & 190 & 100 \\
\hline
\end{tabular}

Based on the multiple choice test results in Table 3, it can be seen that from 691 primary school teachers divided into 282 male teachers and 409 female teachers resulting in a percentage of pedagogical competencies namely $3.2 \%$, including very good categories, $10.5 \%$, including good categories, $67.1 \%$ including the poor category and $19 \%$ including the bad category for male teachers who taught in the lower class. While the male teachers who taught in the high class obtained a percentage of $17.7 \%$ in the good category, $53.8 \%$ in the poor category and $28.5 \%$ in the bad category.

While for female teachers who taught in the lower class, the percentage of $4.6 \%$ was very good, $13.2 \%$, including the good category, $58 \%$ including the poor category and $24.2 \%$ including the bad category. Whereas the female teachers who taught in the high class obtained a percentage of $3.7 \%$ very good, $10.5 \%$ good, 70.5 not good and $15.3 \%$ included in the bad category. In addition to data on pedagogic competencies through multiple choice tests, researchers also collected data on ethnoconstuctivist knowledge through questionnaires in Table 4.

Table 4. Results of knowledge questionnaire ethnoconstivism based on gender

\begin{tabular}{|c|c|c|c|c|c|c|c|}
\hline \multicolumn{5}{|c|}{ Male } & \multicolumn{3}{|c|}{ Female } \\
\hline & Category & Frequency & $\%$ & & Category & Frequency & $\%$ \\
\hline & Very Good & 11 & 7.2 & & Very Good & 21 & 9.6 \\
\hline Low Class & Good & 57 & 37.5 & Low Class & Good & 70 & 32 \\
\hline \multirow[t]{2}{*}{ Teacher } & Not Good & 63 & 41.4 & Teacher & Not Good & 103 & 47 \\
\hline & Very Not Good & 21 & 13.8 & & Very Not Good & 25 & 11.4 \\
\hline \multicolumn{2}{|c|}{ Total } & 152 & 100 & \multicolumn{2}{|r|}{ Total } & 219 & 100 \\
\hline & Very Good & 9 & 6.9 & & Very Good & 19 & 10 \\
\hline High Class & Good & 26 & 20 & High Class & Good & 68 & 35.7 \\
\hline \multirow[t]{3}{*}{ Teacher } & Not Good & 68 & 52.3 & Teacher & Not Good & 92 & 48.4 \\
\hline & Very Not Good & 27 & 20.8 & & Very Not Good & 11 & 5.7 \\
\hline & & 130 & 100 & & Total & 190 & 100 \\
\hline
\end{tabular}

Based on Table 4, it can be seen from 691 teachers consisting of 282 male teachers and 409 female teachers producing data on ethnoconstructivism knowledge with percentages of male teachers teaching in the lower class, namely $7.2 \%$, including very good categories, 37.5 including good categories, $41.4 \%$ including the not good category and $13.8 \%$ included in the very not good category. While male teachers who taught in the high class produced a percentage of $6.9 \%$, including the very good category, $20 \%$, including the good category, $52.3 \%$, including the not good category and $20.8 \%$ including the very not good category.

While data from female teachers who taught in the lower classes produced a percentage of $9.6 \%$ very good, $32 \%$ good, $47 \%$ not good and $11.4 \%$ included in the very not good category. Whereas data on female teachers teaching in the high class yielded a percentage of $10 \%$, including the very good category, $35.7 \%$, including the good category, $48.4 \%$, including the not good category and $5.7 \%$ including the very not good category. The results of ethnoconstructivism knowledge of elementary school teachers in Jambi province based on age range are presented in Table 5. 
Table 5. Results of questionnaire ethnoconstructivistic knowledge based on age

\begin{tabular}{|c|c|c|c|c|c|c|c|}
\hline \multirow{2}{*}{ Age Range } & \multicolumn{3}{|c|}{ Male } & & \multicolumn{3}{|c|}{ Female } \\
\hline & Category & Frequency & $\%$ & & Category & Frequency & $\%$ \\
\hline \multirow{4}{*}{$31-40$} & Very Good & 11 & 19.6 & \multirow{4}{*}{$31-40$} & Very Good & 31 & 33 \\
\hline & Good & 23 & 41.1 & & Good & 27 & 28.7 \\
\hline & Not Good & 13 & 23.2 & & Not Good & 22 & 23.4 \\
\hline & Very Not Good & 9 & 16.1 & & Very Not Good & 14 & 14.9 \\
\hline \multicolumn{2}{|c|}{ Total } & 56 & 100 & \multirow{5}{*}{$41-50$} & Total & 94 & 100 \\
\hline \multirow{4}{*}{$41-50$} & Very Good & 17 & 17.5 & & Very Good & 25 & 18.4 \\
\hline & Good & 25 & 25.8 & & Good & 18 & 13.2 \\
\hline & Not Good & 22 & 22.7 & & Not Good & 43 & 31.6 \\
\hline & Very Not Good & 33 & 34 & & Very Not Good & 50 & 36.8 \\
\hline \multirow{6}{*}{$51-60$} & & 97 & 100 & \multirow{6}{*}{$51-60$} & Total & 136 & 100 \\
\hline & Very Good & 15 & 11.6 & & Very Good & 9 & 5 \\
\hline & Good & 27 & 21 & & Good & 41 & 23 \\
\hline & Not Good & 34 & 26.3 & & Not Good & 57 & 32 \\
\hline & Very Not Good & 53 & 41.1 & & Very Not Good & 72 & 40 \\
\hline & & 129 & 100 & & Total & 179 & 100 \\
\hline
\end{tabular}

Based on Table 5, it can be seen that an ethnoconstructivism knowledge of teachers who were educated in the age range produced a percentage for male teachers, teachers with an age range of 31-40 years produced very good categories $19.6 \%$, good categories $41.1 \%$, not good categories $23.2 \%$ and very not category $16.1 \%$. Teachers with an age range of $41-50$ years produce in the very good category $17.5 \%$, good category $25.8 \%$, not good $22.7 \%$ and very not good category $34 \%$. While teachers with an age range of 51-60 years produce very not good category $11.6 \%$, good category $21 \%$, not good category $26.3 \%$ and very not good category reach $41.1 \%$.

While for female teachers, teachers with an age range of 31-40 years in the very good category reached $33 \%$, good categories $28.7 \%$, not good categories $23.4 \%$ and very not good categories $14.9 \%$. Teachers with a 41-50 year age range in the very good category reached $18.4 \%$, good categories $13.2 \%$, not good categories $31.6 \%$ and very not good categories reached $36.8 \%$. While teachers with a range of 51-60 years in the very good category only $5 \%$, good categories $23 \%$, not good categories $32 \%$ and in the very not good category reached $40 \%$. In addition to obtaining quantitative data, researchers also collected qualitative data through interviews. The first point is how the ethnoconstructivism implementation of the field of mathematics into learning:

a. Ethnoconstructivism learning can be done in the classroom and outside the classroom. Inside that is about the mater while outside the class that is practiced and observation in the school environment. (Teacher interview, 30 November 2018).

b. Learning activities are carried out by using learning methods and strategies. When learning is formed in a group so that peer learning occurs. (Teacher interview, 30 November 2018).

c. Every learning will be easier if you use learning media. When I study, I usually bring media such as pictures and videos about Jambi cultures that have math values. For example, pictures of traditional houses, how the doors, windows. Then what is the size? (Teacher interview, 01 December 2018).

d. For me, learning is mostly done through practice outside the classroom. For example, do traditional games. Students will be divided into teams of the same number. With the learning game, it will be fun. (Teacher interview, 01 December 2018).

e. The implementation of learning mathematics about its culture such as traditional game Engkek - Engkek to facilitate students to understand learning. To make it easier for students to understand learning, learning is done in the classroom and also outside the classroom. Children understand the learning material faster with group learning and children are happier if learning is done outside the classroom." (December 2, 2018).

f. I implement it by replacing the existing examples of the story questions in the textbook into the local culture in Batanghari. (December 2, 2018).

g. It seems like never before, I just heard the term ethnoconstuctivism this time. I usually only refer to the existing textbook. (December 3, 2018).

Based on the opinions and comments of the teachers about the implementation of ethnoconstuctivistic learning shows that the teacher has carried out ethnoconstrutivistic-based learning, namely the use of the environment as a source of learning, using varied learning methods and cultural use and traditional games as a source of pleasant learning. The second point of the question is about the obstacles that teachers encounter when implementing ethnoconstuctivistic learning. Following are the answers and comments from the teachers: 
a. The obstacles I encountered were the abilities of different students. Some students easily grasp learning while others are very difficult. They are more fun playing and not focused on learning. (Teacher interview, 30 November 2018).

b. Ethnoconstuctivism learning is very lacking and difficult to find such as books or student worksheets. So that learning becomes less than optimal. (Teacher interview, 01 December 2018).

c. If in my opinion, the problem is my experience and knowledge of ethnoconstuctivism is still very lacking. So learning is limited. (Teacher interview, 01 December 2018).

d. The obstacle is that currently, the learning media are still very lacking, if I make it myself, the cost is quite expensive. Currently, I am still an honorary teacher. (Teacher interview, 02 December 2018).

e. Constraints are learning resources that integrate with cultural values that are lacking or even non-existent. So I have difficulty in applying in class. (Interview, 03 December 2018).

Based on the answers and opinions of the teachers that the biggest obstacle to the implementation of ethnoconstuctivist learning is the lack of learning resources and learning media, different characteristics of students and lack of experience and knowledge about ethnoconstuctivists.

\subsection{Discussion}

Knowledge of ethnoconstructivism of teachers can be seen from 691 teachers consisting of 282 male teachers and 409 female teachers producing data on ethnoconstuctivistic knowledge with percentages of male teachers teaching in the lower class, namely $7.2 \%$, including very good categories, $37.5 \%$, including good categories, $41.4 \%$ including the not good category and $13.8 \%$ included in the very not good category. While male teachers who taught in the high class produced a percentage of $6.9 \%$, including the very good category, $20 \%$, including the good category, $52.3 \%$, including the not good category and $20.8 \%$ including the very not good category.

Based on these data show that ethnoconstructivism knowledge of male teachers who teach in the lower class is dominant or tends to belong to an unfavorable category with a percentage of $41.4 \%$. The next male teacher who teaches in the high class has ethnoconstuctivistic knowledge that is dominant or less favorable to a percentage of 52.3\%. This shows that male elementary school teachers in Jambi Province have poor ethnoconstuctivistic knowledge. While data from female teachers who taught in the lower classes produced a percentage of $9.6 \%$ very good, $32 \%$ good, $47 \%$ not good and $11.4 \%$ included in the very not good category. Whereas data on female teachers teaching in the high class yielded a percentage of $10 \%$, including the very good category, $35.7 \%$, including the good category, $48.4 \%$, including the not good category and $5.7 \%$ including the very not good category. Based on these data female teachers who teach in the lower classes have ethnocostructivistic knowledge which tends to be less good at $47 \%$. Whereas female teachers who teach in the high class have ethnoconstuctivistic knowledge which tends to or less favorably with a percentage of $48.4 \%$. From this data shows that female elementary school teachers in Jambi Province have poor ethnoconstuctivistic knowledge.

According to Act No. 16 of 2007 point 1 that Pedagogical Competence of teachers must understand the characteristics of students from physical, moral, social, cultural, emotional and intellectual aspects [10]. It shows that in carrying out learning, the teacher must integrate the cultural values and social-cultural background of the students. This means that teachers are required to carry out learning must follow the cultural and social-cultural values of students. Having knowledge about culture and social-culture of students means that the teacher has fulfilled the demands of pedagogical competencies that must be mastered by the teacher. Knowledge of good teacher ethnoconstivism can support the implementation of effective learning. The teacher's role consists of various roles consisting of culture. This implies facts and environment when determining how the teacher's role is developed, and influences how it solves in different cultures, communities and geographical environments. Thus, it is difficult to offer a resolution that addresses the role of teachers without considering cultural, geographical and social differences [25, 26]. Having poor ethnoconstructivism knowledge shows that the teacher has not mastered pedagogical competence well. The teacher has not been able to make the cultural background of the students as part of learning in the classroom.

Based on 691 elementary school teachers divided into 282 male teachers and 409 female teachers resulting in a percentage of pedagogical competencies, 3.2\%, including the very good category, $10.5 \%$, including the good category, $67.1 \%$, including the not good category and $19 \%$ including the category very not good for male teachers who teach in low class. While the male teachers who taught in the high class obtained a percentage of $17.7 \%$ in the good category, $53.8 \%$ in the not good category and $28.5 \%$ in the very not good category. This shows that the male teacher's pedagogical competence teaching in the lower class is dominant or tends to be less good with a percentage of $67.1 \%$, while the male teacher who teaches in the high class has pedagogical competency which tends to be or less dominant $53.8 \%$. This means that male elementary school teachers in Jambi Province have poor pedagogical competencies. 
While for female teachers who teach in the lower class, the percentage of $4.6 \%$ is very good, $13.2 \%$ is in the good category, $58 \%$ is in the not good category and $24.2 \%$ is in the very not good category. Whereas the female teachers who taught in the high class obtained a percentage of $3.7 \%$ very good, $10.5 \%$ good, $70.5 \%$ not good and $15.3 \%$ included in the very not good category. Based on these data, it shows that pedagogical knowledge of female elementary school teachers who teach in the lower class tends to be or less dominantly dominant at $58 \%$. While female teachers who teach in the high class have pedagogical knowledge that tends to or less dominantly with a percentage of $70.5 \%$. Based on these data shows that male and female teachers in elementary schools have poor pedagogical knowledge. Competence has a very important role. Competence contains principle values in learning. Teacher competencies as a requirement for achieving synergistic effects: teacher competencies for cognitive processing processes (e.g., knowledge in the broadest meta-cognitive strategies), teacher competencies for effective promoting- motivational processes, and teacher competencies for promoting social processes in students [27]. This means that mastery of good competencies for teachers is very important. Teachers who have good pedagogical competencies will support teachers in implementing good learning. Teachers who have poor competence show that teachers are less professional. Therefore, an increase in a teacher's pedagogic competence is absolutely necessary. The increase can be done in various ways. Lesson study is a systematic investigation of classroom pedagogy conducted by a group of teachers rather than individuals, with the aim of improving the quality of teaching and learning [22].

Whereas when viewed from an ethnoconstructivist knowledge of the mathematical field of teachers based on age, it can be concluded that the older the teacher, the lower ethnoconstuctivistic knowledge or in the bad category. It can be seen that male teachers in the age range of 31-40 years tend to be in the good category. Male teachers in the 41-50 year age range tend to be dominant in the worst category, while male teachers in the age range of 51-60 years are also dominantly categorized as not good.

While for female teachers, teachers in the age range of 31-40 years are in the good category, teachers who are in the 41-50 year age range tend to be dominant or not in the good category. While teachers with ages ranging from 51 to 60 years are also dominant in the category that is not good. Age has a significant influence on teacher knowledge about ethnoconstivism. Teachers of an age who are older should not understand new things in the development of education. Young teachers should have good knowledge of renewable and more creative knowledge. The advantage of senior teachers is having more experience than younger teachers. Many positive and negative views have been put forward regarding age and teaching. It is a general thought that is as advanced and designation is promoted, teachers lose the enthusiasm to teach. Another thought is the age and experience go hand in hand. Age is an asset [28].

Mathematics lessons are often considered a scary lesson for students. This has become a challenge for teachers to do the intense mathematics learning for students. One of the challenges currently faced by students is the rules and contents of mathematics in a more effective, fun, and successful way [21]. The argument for the past few years has revolved around the cultural contribution to the promotion of mathematics taught in schools. Learning mathematics can be done through a constructivist approach by assimilating new knowledge and past experiences of students actively forming their own meanings. Constructivism can be understood as an epistemological paradigm, inside of which the aforementioned postmodernist relativism is perhaps most clearly manifested. By integrating cultural values into learning mathematics will make students feel close to their environment [29]. Students also become easy to understand learning material because learning is not imagined but more concrete and real. Learners can combine mathematical concepts with their experiences. In the framework of constructive learning, especially in the field of mathematics, students are encouraged to actively promote the development of their own effective learning concepts and can suggest ideas to improve future learning [30].

The ethnoconstructionist term in the field of mathematics is still very foreign to the teachers. However, a small number of teachers have implemented mathematics learning with local cultural values and wisdom in a very simple way or strategy. The teacher uses learning media in the form of pictures or photos. Some other teachers implement it by doing traditional games outside the classroom. Cultural values, for example, traditional house drawings and traditional games are useful for delivering students to form their own knowledge. The theory of constructivism is all about paradigm, believing that learning is an active and constructive process. Constructivism is about the nature of knowing, learning and teaching. It is a change in meaning through experience [31]. Cultural values and local wisdom such as traditional games make learning meaningful through real activities in accordance with constructivist theory. The theories of constructivism are all about paradigm, believing that learning is an active, constructive process that takes place in a socialcultural situation. Learners are designed to be active to change in meaning through real activities [31]. Constructivism encourages social interaction among students. This is a way to develop the skills needed to learn about people's skills and skills to develop their communication skills [32]. Integrating cultural values and local wisdom as part of student experience can increase student motivation. According to [33], their 
cultural and living experiences should be used to learn the best so that their motivation for learning and learning outcomes can be improved. The use of methods and learning strategies makes it easier for teachers to deliver learning. The use of methods and learning strategies shows professional teachers. Cultural values and local wisdom contain educational values. Local wisdom which is scattered throughout Indonesia has one thing in common, it cultivates attitudes, behaviors, and morality [34].

While the obstacles experienced by teachers in the process of implementing ethnoconstivism-based learning in mathematics learning are the lack of media and learning resources. Though the existence of media and learning resources facilitate the process of transferring knowledge to students in the learning process [35]. Learning is a process of transferring knowledge to students through teaching and learning processes. In addition, the characteristics of different students make it difficult for teachers to carry out ethnoconstuctivist-based learning in mathematics. Students have varied enthusiasm and learning motivation. Most students fuss and joke with other students. The teacher becomes a difficulty in regulating and conditioning students in the classroom. Therefore, teachers need to understand the characteristics of students well [36]. Teachers need to understand the learner through learners' characteristics, primarily on things related to aspects of intellectual, emotional, moral and background of learners. It is intended to be smooth, so that the learning objectives can be achieved. In the implementation of learning, teachers identify prior knowledge students. The limited knowledge and experience of teachers about ethnoconstuctivism are also obstacles. The teacher has in-depth knowledge and experience about the local culture and wisdom around. Status as a contract teacher or "honorary" makes the teacher's performance decrease and lack enthusiasm in work.

The integration of cultural values and local wisdom into mathematics is very important. Understanding of cultural values and local wisdom in students makes students understand their national identity. Learning with culture can make interested students in their local culture and increase students' appreciation of local culture. Culture-based learning is also the impact of constructive learning [37]. Based on the dominance analysis, teacher lesson plan has integrated cultural values and local wisdom to form and assist students in finding mathematical concepts. The teacher uses the surrounding environment as a learning resource that makes it easy for students to find their own concepts.

Table 6 shows that 691 respondents from teacher, elementary school in Jambi province, Indonesia have been processed using the SPSS program. Table 6 shows that the results of mean 38.2, maximum value 51 , minimum value 14 , for male teacher especially in low class teacher. The table also informs that the results of mean 35.5, maximum value 50, minimum value 15, for female teacher especially in low class teacher. While for the male teacher in high class teacher it was found that the results of mean 34.3, maximum value 50, minimum value 15 , and than for teacher female in high class teacher it was found that the results of mean 36.5 , maximum value 50, minimum value 16 .

Table 6. Effects of ethno-constructivism on mathematical pedagogic competencies

\begin{tabular}{|c|c|c|c|c|c|c|c|c|c|c|c|c|c|}
\hline & \multirow{2}{*}{ Variable } & \multicolumn{6}{|c|}{ Male } & \multicolumn{6}{|c|}{ Female } \\
\hline & & Min & Max & $\mathrm{X}$ & $\mathrm{P}$ & $\mathrm{R}$ & $\mathrm{R}^{2}$ & Min & Max & $X$ & $\mathrm{P}$ & $\mathrm{R}$ & $\mathrm{R}^{2}$ \\
\hline $\begin{array}{c}\text { Competence } \\
\text { Pedagogy in Low } \\
\text { Class Teacher }\end{array}$ & $\begin{array}{l}\text { Ethnocontruc } \\
\text { tivism }\end{array}$ & 14 & 51 & 38.2 & 0.02 & 0.85 & 0.7 & 15 & 50 & 35.5 & 0.02 & 0.85 & 0.72 \\
\hline $\begin{array}{l}\text { Competence } \\
\text { Pedagogy in High } \\
\text { Class Teacher }\end{array}$ & $\begin{array}{l}\text { Ethnocontruc } \\
\text { tivism }\end{array}$ & 15 & 50 & 34.3 & 0.02 & 0.83 & 0.6 & 16 & 50 & 36.5 & 0.02 & 0.83 & 0.69 \\
\hline
\end{tabular}

From the Table 6 we can see that the sig value is 0.02 small than 0.05 , it can be concluded that there is an ethno-constructivism influence on mathematics Pedagogic Competence in the lower classes for male teachers. The contribution of the effect is $70 \%$ and other factors are $30 \%$. Then for low class female teachers that the sig value of 0.02 is small than 0.05 , it can be concluded that there is an ethno-constructivism influence on the mathematics Pedagogic Competence. The contribution was $72 \%$ and other factors were $28 \%$. While the value of sig 0.02 is smaller than 0.05 , it can be concluded that there is an Etna-constructivism influence on mathematics Pedagogic Competence in the high class for male teachers. The contribution is $60 \%$ and other factors are $40 \%$. Whereas for high-class female teachers that the sig value is 0.02 small than 0.05 , it can be concluded that there is an ethno-constructivism influence on mathematical Pedagogical Competence. While the influence is $69 \%$ and other factors are $31 \%$.

The teacher's ability is related to the theoretical mastery of ethno-constructivism and its application process in learning both in managing learning by designing and implementing ethnoconstructivism learning processes in accordance with the prevailing educational foundation. This is in accordance with the national education system law which states that the learning process at the elementary school must be based on

Ethnoconstructivism analysis: Study of pedagogic mathematics competence of primary school ... (Syahrial) 
the value of local wisdom. Ethnoconstivism is an integration in the form of student knowledge of using and integrating cultural values and the ability to develop the potential of students by teachers based on local wisdom values. Rewards contingent on task performance or level of achievement can, therefore, affect the forces of intrinsic motivation negatively [38, 39]. In addition, the factors that influence teacher performance include: Exercise and work experience, education, personality, attitudes, social conditions, individual needs, physical condition of the workplace, abilities, and work motivation. The pedagogical competences in close connection with three important factors of education: educational achievement/success/efficiency, professional development and societal change. That the expected pedagogical competence of primary school teachers must master the effective teaching method and manage the learning process. Elementary school teachers must master broadly and deeply the mathematics subject matter which is specifically taught by applying ethnoconstivism in mathematics learning [40]. Mathematical knowledge in teaching is the center of the individual teacher or social asset, meaningful only in the context of mathematical applications. Primary school teachers in order to guide their students in obtaining competencies that have been determined according to the law must be innovative based on ethnoconstivism. Pedagogical competence becomes very important in determining the success of the learning process that directly touches learning abilities which include management of students, planning, process design learning, evaluation of learning outcomes, and development of students.

Teacher who has and controls high ethnocontructivism skills, the teacher can teach students well. Mastering ethno-constructivism can make it easier for teachers to make learning in the classroom. Students will easily understand mathematics learning material because learning becomes contextual and close to the lives of students. So that it is very helpful for students in facing mathematics learning that is considered scary. Cultural processes are very closely related to values and problems in the community. Teachers' creative attitudes have become an essential element of the educational initiatives. This is largely because cultural and social transformations demand a more innovative teaching process and a faster, more complete development of teachers' and students' creative abilities [41]. If the teacher does not have ethnononstructivism skills and is unable to implement it into learning it will have an impact on the students' love for their own culture which will fade. Then the learning will become students will fantasize in learning. Educational values contained in local wisdom can be used as part of improving national character. Local wisdom is possessed by Indonesian people has a role to build the character of a nation, such as mutual assistance, religious tolerance and so forth [42]. Ball [14], Ward [43], Ward [44] have differentiated between two forms of related, yet different, content knowledge. The low pedagogical ability of teachers is due to the still low number of teachers in applying ethnoconstructivism to mathematics learning due to the age of the teacher. Teachers who have aged 45 years and above who usually use traditional media, models and learning strategies, now with the development of the industrial revolution 4.0 era; teachers are required to upgrade or develop media, models and strategies in teaching. It is because teachers who have aged 45 years and over are stuttering with technology.

\section{CONCLUSION}

Cultural values and local wisdom cannot be separated from human life. Cultural values and local wisdom as a result of life processes contain many values of education. Therefore the teacher must integrate cultural values and local wisdom into learning. Ethnoconstivism in the field of mathematics encourages the integration of cultural values and local wisdom into mathematics learning. The implementation of ethno-constructivism-based learning in mathematics is closely related to pedagogical competence. Based on the results of the research, pedagogic competencies in male teachers as a whole tend to be dominantly not good. Meanwhile, female teachers also tend to be dominant not good.

While the level of ethnoconstructivism knowledge of male teachers as a whole also tends to be dominated not good. In teaching teachers also tend to be less dominant. Whereas if seen by age range, overall male and female teachers with a range of 31-40 years are in the good and the very good category. While in the range of 41-50 years, it tends to be in the category of bad and not good. In the age range of 51 - 60 years, the male and female teachers are in a bad category. This shows that the older the age of a teacher has a tendency to low ethnoconstructivism knowledge.

Some teachers have implemented ethnoconstivism-based learning in mathematics learning in various ways, such as using learning methods and strategies, using simple learning media and using the surrounding environment as a learning resource. But the teacher still has constraints such as the lack of media and learning resources about ethnoconstivism in mathematics learning and the varied characteristics of students. In addition, the teacher felt that his experience and knowledge of ethnoconstivism was still very low. Especially for teachers in elementary schools to build a national identity. The significant pre-service teacher education role should play programs, not only in preparing student teachers with necessary teaching 
techniques and skills but also in helping them to build strong and positive professional identity to cope with the complex demands and possible challenges in their future work.

\section{ACKNOWLEDGEMENTS}

The researcher expressed his gratitude to all elementary school teachers in Batanghari District, Muaro Jambi Regency and Jambi City for their participation and cooperation. The researcher also thanked the Education Office of Batanghari Regency, Muaro Jambi Regency and Jambi City for their support and cooperation. This research is funded by superior tertiary applied research grants from the Directorate General of strengthening research and Development of the Indonesian Ministry of Research, Technology and Higher Education (Ristekdikti) with Jambi universities through contract number 060/SP2H/LT/DRPM/2019 dated December 052018.

\section{REFERENCES}

[1] C. Kaendler, et al., "Teacher competencies for the implementation of collaborative learning in the classroom: A framework and research review," Educational Psychology Review, vol. 27, no. 3, pp. 505-536, 2015.

[2] L. Shulman, "Knowledge and teaching: Foundations of the new reform," Harvard educational review, vol. 57, no. 1, pp. 1-23, 1987.

[3] M. B. Nemet, "A Correlation between Teachers' Social and Pedagogical Competences and School Culture. Sodobna pedagogika," Journal of Contemporary Educational Studies, vol. 69, no. 3, pp. 142-155, 2018.

[4] L. S, Shulman and J. H, Shulman, "How and what teachers learn: a shifting perspective," Journal of Curriculum Studies, vol. 36, no. 2, pp. 257-271, 2004.

[5] L. S. Shulman, "Those who understand: Knowledge growth in teaching," Educational Researcher, vol. 15, no. 2, pp. 4-14, 1986.

[6] L. Shulman and D. Sparks, "Merging Content Knowledge and Pedagogy: An Interview with Lee Shulman," Journal of Staff Development, vol. 13, no. 1, pp. 14-16, 1992.

[7] J. H. L Koh., et al., "Examining the technological pedagogical content knowledge of Singapore pre-service teachers with a large-scale survey," Journal of Computer Assisted Learning, vol. 26, no. 6, pp. 563-573. 2010.

[8] J. Maksimovic, et al., "Teachers as reflective practitioners with the function of improving educational practice in primary schools in Serbia," Journal of Contemporary Educational Studies, vol. 69, no. 4, pp. 306-324, 2018.

[9] A. Akmal, "Local Culture and Morality Attachment To Tpack Framework of Pre-Service English Teachers Within The Challenge Of The 21st Century Skills," International Juornal of Education, vol. 9, no. 2, pp. 113-120, 2017.

[10] Low no. 16 of 2007, Concering teacher competency and qualification standarts.

[11] M. Koutouzis and K. Spiriadou, "The Interaction between Professional and Social Identity of Greek Primary School Educators," International Journal of Education, vol. 9, no. 4, pp. 190-209, 2017.

[12] D. Bransford, et al., How People Learn: Brain, Mind, Experience, and School. Washington D.C: National Academy Press, 2000.

[13] Darmaji, Astalini, D. A. Kurniawan, N. Sari, O. H. Wiza, and Y. E. Putri, "Investigation of Students' Psychology: The Relationship among Students' Attitudes, Persistence, Creativity, and Tolerance toward Natural Science Subjects," Universal Journal of Educational Research, vol. 8, no. 4, pp. 1155-1166, 2020.

[14] D. L Ball, M. H. Thames, and G. Phelps, "Content knowledge for teaching: What makes it special?" Journal of Teacher Education, vol. 59, no. 5, pp. 389-407, 2008

[15] J. Mason and B. Davis, "The Importance of Teachers' Mathematical Awareness for In-the-Moment Pedagogy," Canadian Journal of Science, Mathematics and Technology Education, vol. 13, no. 2, pp. 182-197, 2013.

[16] D. L Ball, L. Sleep, T. A. Boerst, and H. Bass, "Combining the Development of Practice and the Practice of Development in Teacher Education," The Elementary School Journal, vol. 109, no. 5, pp. 458-474, 2009.

[17] A. Sriwongchai, et al., "Developing the Mathematics Learning Management Model for Improving Creative Thinking in Thailand," International Education Studies, vol. 8, no. 11, pp. 77-87, 2015.

[18] M. Rosa and D. C, Orey, "Ethnomathematics: the cultural aspects of mathematics," Revista Latinoamericana de Etnomatemática, vol. 4, no. 2, pp. 32-54, 2011.

[19] O. A. Cimen, "Discussing Ethnomathematics: Is Mathematics Culturally Dependent?" Procedia - Social and Behavioral Sciences, vol. 152, no. 2, pp. 523-528, 2014.

[20] A. Arisetyawan, D. Suryadi, T. Herman, and C. Rahmat, "Study of Ethnomathematics: A lesson from the Baduy Culture," International Journal of Education and Research, vol. 2, no. 10, pp. 8-15, 2014.

[21] A. Q, Fouze and M. Amit, "Development of Mathematical Thinking through Integration of Ethnomathematic Folklore Game in Math Instruction," Eurasia Journal of Mathematics, Science and Technology Education, vol. 14, no. 2, pp. 617-630. 2017

[22] A. Fouze and M. Amit, "On the Importance of an Ethnomathematical Curriculum in Mathematics Education," Eurasia Journal of Mathematics, Science and Technology Education, vol. 14, no. 2, pp. 561-567. 2017.

[23] M. Kohl, et al., Sampling Methods, Remote Sensing and GIS Multiresource Forest Inventory. Springer, 2006.

[24] J. W. Creswell, Research Design Qualitative, Quantitative, And Mixed Method Aproach. Singapore: SAGE Publications Asia-Pacific, 2009.

[25] S. Gudmundsdottir and L. Shulman, "Pedagogical Content Knowledge in Social Studies," Scandinavian Journal of Educational Research, vol. 31, no. 2, pp. 59-70, 1987.

Ethnoconstructivism analysis: Study of pedagogic mathematics competence of primary school ... (Syahrial) 
[26] D. Mekovec, “The Dimensions of Teacher's Professional Development," Sodobna pedagogika/Journal of Contemporary Educational Studies, vol. 69, no. 3, pp. 106-125, 2018.

[27] C. Peklaj, "Teacher Competencies through the Prism of Educational Research," Center for Educational Policy Studies Journal, vol. 5, no. 3, pp. 183-204, 2015.

[28] S. R. Shah and U. S. Udgaonkar, "Influence of Gender and Age of Teacher on Teaching: Students Perspevtive," International Journal of Current Microbiology and Applied Sciences, vol. 7, no. 1, pp. 2436-2441, 2018.

[29] T. Vidmar, "School and the Understanding of Knowledge between Pragmatism and Constructivism," Journal of Contemporary Educational Studies, vol. 37, no. 1, pp. 1-10, 2011.

[30] A. S. Troelstra and D. Van Dalen, Constructivism in mathematics (Vol. 2), Teaching and Teacher Education. Elsevier, vol. 23, pp. 1289-1301. 2014.

[31] K. Y. Nugroho, "Constructivist Learning Paradigm as the Basis on Learning Model Development," Journal of Education and Learning (EduLearn), vol. 11, no. 4, pp. 410-415, 2017.

[32] D. Porcaro, "Applying constructivism in instructivist learning cultures," Multicultural Education \& Technology Journal, vol. 5, no. 1, pp. 39-54, 2011.

[33] J. Chao, C. H. Liu, and Y. H. Yeh, "Analysis of the learning effectiveness of atayal culture cps spatial concept course on indigenous students," Eurasia Journal of Mathematics, Science and Technology Education, vol. 14, no. 6, pp. 2059-2066, 2018.

[34] A. Hasanah, N. Gustini, and D. Rohaniawati, "Cultivating character education based on sundanese culture local wisdom,” Jurnal Pendidikan Islam, vol. 2, no. 2, pp. 231-253, 2016.

[35] D. Sugandi, N. Trianawati, and L. Somantri, "The Learning Model Used in the Teaching and Learning Process of Environmental Damage in Bandung Basin," International Journal of Education, vol. 9, no. 3, pp. 21-35, 2017.

[36] M. H. Rahman, "Professional Competence, Pedagogical Competence and the Performance of Junior High School of Science Teachers," Journal of Education and Practice, vol. 6, no. 2, pp. 1-12, 2014.

[37] W. W. Cobern, Contextual constructivism: The impact of culture on the learning and teaching of science, The practice of constructivism in science education. Routledge, 2012.

[38] Astalini, D. A. Kurniawan, Darmaji, M. Ikhlas, Kuswanto, R. Perdana, L. Anggraini, and I. Putra, "Attitude and Self-confidence Students in Learning Natural Sciences: Rural and Urban Junior High School," Universal Journal of Educational Research, vol. 8, no. 6, pp. 2569-2577, 2020.

[39] M. C. Poona, "Dev Intrinsic Motivation and Academic Achievement What Does Their Relationship Imply for the Classroom Teacher?" Remedia L An D Specia L Education, vol. 18, no. 1, pp. 12-19, 1997.

[40] K. Gabriele, et al., "Professional knowledge of (prospective) Mathematics teachers-Its structure and development," Cuadernos de Investigación y Formación en Educación Matemática, vol. 11, no. 15, pp. 83-99, 2016.

[41] A. Kozuh, "Creativity: Didactic Challenge of a Modern Teacher, "Sodobna pedagogika/Journal of Contemporary Educational Studies, vol. 69, no. 3, pp. 156-169, 2018.

[42] B. Subali, A. Sopyan, and E. Ellianawati, "Developing local wisdom based science learning design to establish positive character in elementary school," Jurnal Pendidikan Fisika Indonesia, vol. 11, no. 1, pp. 1-7, 2015.

[43] P. Ward, S. Ayvazo, and H. Lehwald, "Using Knowledge Packets in Teacher Education to Develop Pedagogical Content Knowledge," Journal of Physical Education, Recreation \& Dance, vol. 85, no. 6, pp. 38-43, 2014

[44] P. Ward, W. Li, I. Kim, and Y.S. Lee, "Content knowledge courses in physical education programs in South Korea and Ohio," International Journal of Human Movement Science, vol. 6, no. 3, pp. 107-120, 2012. 